JAGODA ŠARIĆ, PhD students, University of

Belgrade Faculty of Architecture,

Belgrade, Serbia

jagoda.saric@yahoo.com
UDC: 069.5:902 ; 727.7:902/904

Original research article Received: March 04 2013

Accepted: October 15 2013

IVA MARKOVIĆ, PhD students, University of

Belgrade Faculty of Architecture,

Belgrade, Serbia

MLADEN PEŠIĆ, PhD students, University of

Belgrade Faculty of Architecture,

Belgrade, Serbia

\title{
CONTEMPORARY EXHIBITION-ARCHITECTURAL CONCEPT IN THE PRESENTATION OF ARCHAEOLOGICAL HERITAGE
}

\begin{abstract}
This paper has the aim to examine new discourses and knowledge of past practices through relevant examples in the presentation of the past. During the research of contemporary exhibition and architectural concepts, the intention is to study and show the invisible alternative history through the exhibition as a medium, where history is interpreted as a constructed narrative. In addition, the idea is to study the contemporary exhibition interpretations of historical heritage, as a form of production of contemporary architectural practice. Past has two levels of observation: on the one hand, what happened once remains unchanged forever, but on the other hand, the explanation or interpretation is changed. One of the main objectives of the research will be searching for the answer to the question on how it is possible to remember, reconstruct and recycle the past through the presentation of historical heritage. In social memory theories, by storing certain contents and forgetting others, information from the past is brought into the specific line, or the system that becomes the basis for the interpretation of the world. Culture of remembrance, which includes all forms of public use of memory, studies the mechanisms of social transmission, design, maintenance and processing of the past. The term memory is interpreted as the storage of the past, but on the other hand, the memory, according to Todor Kuljic, is "the grip into the past always from the new present". Memories activate and once again bring up the burning question of the content of the past with the aim of interpreting the present and constructing a vision of the future and in that sense the memory is not a true view of the past, but "the result of construction and reality", i.e. the interspace between stories and historical facts. Passing of time also means recognition and distance, which cultural monument always tends to overcome. Due to its physical presence, it aims to create an error in time and establish a direct connection with the events and individuals it memorizes. The main role of the intentional monuments is to keep memories alive and as Alois Riegl states, "the deliberate value of remembrance simply requires immortality, eternal present and continuous existence."
\end{abstract}

Keywords: memory, history, exhibition, presentation, medium, archaeological presentation. 


\section{INTRODUCTION}

As well as all cultural objects, monuments and archaeological heritage, when they are displayed in an exhibition, they form a complex system which is the result of the relationship between exhibits themselves, concepts of their exposure and physical framework, i.e. the space where they are exhibited. Cultural monuments convey a deliberate testimony about a particular time, place or event within the historical and social time (context), but also, they often carry a different, unintended meaning. On a general level, for each monument and every form of its presentation, one might ask about relations and meanings they produce when time and social relations are transformed into material form, or when they are summarized into space which becomes our measure and way of understanding from that moment on.

While building the social identity, it is of great importance to have the process of establishing and accepting certain values through the creation of common culture of memory, and every representation of the past that stands as its part. Spatial articulation of memory is a complex artificial set of different aesthetic and social values. Spaces where the past is represented are the places where not only desirable common memories are constructed, but also values that construct the present, i.e. anticipated future, are indicated. Exhibition is not the medium where the monument is exhibited; exhibition space "does not mean the action of extending items, but the action of their relationship.”(Premerl, 1970: 70) The key question of this paper is the theoretical relationship between exhibition, memory and cultural monuments that have influence on the interpretation of the past.

The mainidea of this paper is to use summarized theoretical consideration, i.e. the definition and comparative analysis of the key concepts related to the culture of memory and practice of exposure, as well as the parallel display of relevant examples of contemporary exhibition and architectural concepts of presenting archaeological heritage, to review new discourses and knowledge about practices in the presentation of the past. The aim is to reflect on how to explore archaeological heritage from the position of architectural discourse and to isolate possible research questions.

\section{PAST, CULTURE OF MEMORY, MONU- MENTS, EXHIBITIONS}

By keeping certain contents and forgetting others, information from the past are brought into certain order, i.e. the system which becomes the basis for interpreting the world. Past has two levels of observation: on the one hand, what happened before remains unchanged forever, but on the other hand, explanation or interpretation is changed. Culture of memory, which includes all forms of public use of memory, belongs to the level of interpretation and explanation of various forms of preserving and presenting the past. The phenomenon of memory contains two not confronted but complementary terms, and those are memory and remembrance which are not always possible to be terminologically distinguished. Memory is the capability of storage, i.e. keeping the contents from the past, while the remembrance is an active process of «imprinting and actualization»(Asman, 1999: 121) of specific contents(ibid: 121-135), or according to Todor Kuljic, "an intervention in the past always from the new present." (Kuljić, 2006:8) Memory triggers and once again actualizes the contents of the past in order to interpret the present and construct visions of the future, and regarding this, the common memory is not the true vision of the past, but "the result of construction and reality"(ibid.), i.e. placed into space between stories and historical facts.

In an important text, "The modern cult of monuments: its essence and its meaning” (1903), Alois Riegl (Reigl, 1996: 69-83) deals with the theoretical elaboration of the meaning of monuments (expressed in the system of protection of cultural heritage), the original values( ibid. $)^{1}$ and different perceptions of the monument. At the very beginning he defines a monument as a «man-made creation, built with the purpose to keep certain personal acts and events vivid in the minds of future generations»(ibid.: 69) and concludes that both unintentional and intentional monuments are determined by monumental values. The key difference is that the values of intentional monuments

1 Riegl distinguishes three types of monuments values: intentional monumental value (gewollte Erinnerungswert), historical value (historic Welt) and age value (Alteswert). In author's proposed concept of age, the monument logic is inverted transience, before durability becomes its characteristic. Ibid. pp 69-83. 
are always determined in the moment of creation, while the values of unintentional monuments are always relative and are the case of subjective, rather than objective marking. According to Riegl's primarily visual analysis, the meaning is determined at the time of perception and the observer is the one that actually constitutes the monument.

Passing of time also means recognition and distance, which intentional monument always wants to overcome. By its physical presence, it has the intention to create an error in time and establish a direct connection with event or individuals it memorizes. The main role of intentional monument is to keep memories alive and as Riegl states - "a thoughtful value of remembrance simply requires immortality, eternal present and continuous existence."(ibid.:78).

It is necessary to consider the spatial meaning of the monument through the simultaneous relationship between space and form, i.e. to examine the spatial phenomenon of monument presentation and space it enables and builds. The relationship between cultural monuments and architecture is determined by the fact that the exposure takes place within a space gallery, museum or other exhibition area. The exhibition is always pre-defined by its physical frame; while on the other hand, the architecture of each exhibition is a place, framework, boundary within which the exposure takes place. Exhibitions can also be defined as phenomena that are limited by space and time(Alpers,1991: 26), and in contemporary interpretation they can be understood in three aspects - as a medium, an institution and an independent art form. Medium of the exhibition, as well as all the media, is very often determined by some other medium: architecture of exhibition space, light, colour, printed material and catalogues, and of course the exhibits themselves (Curley, 2004).

In a variety of different definitions, one of the exhibition definitions provided by Ivo Maroevic says that exhibitions are «events where the society and time meet and connect in space.»(Maroević, 1994: 290). According to this definition, exhibition is determined as an event while at the same time exhibitions can be defined as a place where public opinion is «produced» and «constituted» but also as the place where the exchange of certain (social) values and powers takes place(Bennett, 1996: 82). Editors of the book "Thinking about Exhibitions" agree with the definition of exhibition as a place of exchange and say that "exhibitions are the primary place of exchange in the political economy of art, where the importance is constructed, maintained and occasionally deconstructed. Partly a spectacle, partly a socio-historical event (the fact), and partly a structuring tool, exhibitions set up and frame the cultural significance of art."(Greenber, 1996: 2).

Although the presentation of archaeological heritage actually means confirmed and unchangeable historical facts, these exhibitions do not include the complete and closed systems. Their meanings and valuation change, expand and invert according to the way of conceptualization of reality in time and space within which the particular exhibition is interpreted(Gavrilović, 2009: 2).

Depending on the context within which it is interpreted, the concept of exhibition can be understood on many levels. Since this is about a complex social phenomenon, depending on the way of observation, exhibitions are determined doubly, as an act of "public display" (works of art, manufactured goods, things from nature, etc.) and as "the space where the exhibition takes place.”(Kastelić, 2011) Defined this way, exhibition exists both as an event and space, i.e. as action and place (location)(ibid.). Considered as events, exhibitions are almost always a set of psychological, aesthetic and ideological layers, and thus can be interpreted and understood only if they are perceived and understood on the broader horizon of social events. Seen as a place, exhibition spaces are full of discourse, exhibition is not only what appears to the eye, and not only does it include a superficial picture or display, but it also includes a set of ideas, languages and mechanisms within which it is materialized using mostly the world of art and culture as the mechanism of meaning and purpose production (ibid.).

Each monument represents one part of the past i.e. the values and meanings it takes. The concept of representation can be defined as "something that stands instead of something else" (Ddanto, 2006: 165), and representation is also the production of meaning through language. This concept has a place in the study of culture because it connects meaning and language with culture, and in that sense Stuart Hall distinguish- 
es a constructivist theory because he recognizes the social nature of language, i.e. as he states, "things are not meaningful : we construct the meaning.”(Hall, 1997: 13-75) On the other hand, Ginzburg points out the ambiguity which the concept of representation contains, and which can be clearly seen through the monument itself. The monument stands instead of the reality it presents, and in that way, it recalls absence, while it simultaneously makes the reality visible and thus suggests the presence (Ginzburg, 2002: 63-89).

Memory implies emotional and cognitive relationship of the individual to his or her personal experience, and although it is never a fully unconscious activity, it always contains unintentional perception and unconscious reaction. That is an active creative process where the original experience is not reproduced, but with the help of "memory traces"(Kuljić, 2006: 57) the image of that experience is reconstructed. Models of memory within the memory theories differ according to the pictures which should be remembered, i.e. according to the complex system of metaphors which is not the language used to describe the subject of memory, but the way it is revealed and constituted. Picturesque is basically the idea of memory, and according to Aleida Assman, images "serve as figures of thought which limit the conceptual fields and according to them, the theory is oriented"(Asman, 1999: 121).

On the other hand, memory is the part of society and culture where the results of memories are stored, and it implies "a deliberate approach to the past"(Kuljić, 2006: 11) and often belongs to the institutional apparatus of society. Because of its constant change, it cannot be considered a passive activity.

Memories are the plays that reconstruct the past from the immediate present, but they also contain reconstructions of the past, closer or further periods of the past, or how Maurice Halbwash points out, "memory is an image dressed in other images, a generic image transferred to the past"(Albvaš, 1999: 74). ${ }^{2}$ However, in our mem-

2 In the 1920s, , the French sociologist Maurice Halbwash was the first to theoretically considered social frameworks of memory, considering that although in the physical sense only individuals remember, and social groups define and construct the memory. Moris Albvaš, „Kolektivno i istorijsko pamćenje“, REČ- časopis za književnost i kulturu, $i$ društvena pitanja (Beogard), br. 56.2 (1999), 74. ory, already seen pictures of the past do not last, but according to Halbwash, the thing that survives in one society are the signs that provide constant reconstruction of certain parts of the past. Memory is always followed by oblivion, or how Aleida Assman states "we can remember only if we are able to forget.”(Asman, 2011: 72) Unconscious or often deliberately set in a social sense, oblivion is not actually the opposite of memory, but an inseparable and indispensable part of its complex selective mechanism. If the memory triggers contents of the past from current perspective, then the oblivion is actually "deactualization of the part of our experience"(Kuljić, 2006: 61) and within cultural theories it is particularly interesting as an intentional strategy used to bring the contents of the past to a certain order.

\section{CONCLUSION}

Within the grasp that the field of architecture involves not only creation in order to meet spatial and utilitarian needs, but also contains the field of theoretical considerations which represent the first step in the process of objectification in the form of concrete objects or patterns of activity, this paper examines theoretical consideration as the basis for studying archaeological heritage from the position of architectural discourse. In that sense, analysis was presented and relationships were established between the concepts of monument, exhibition, representation and memory, which were highlighted as crucial.

In additional research, besides the idea to explore contemporary interpretations of exhibiting cultural heritage as one of the forms of production of contemporary architectural practice, the intent is to examine and present the invisible, alternative history through exhibition as a medium, where history is interpreted as a constructed narrative. It is necessary to examine the way of understanding the past, and therefore the social frameworks that generate it, which depends on the construction of memory and the way it is changed. This approach is consistent with contemporary research about the culture of memory, which raises the question on how at some point of time a specific place (Prlenda, 2006: 21-43). ${ }^{3}$ forms the

3 According to Pierre Nora, places of memory occur at the moment when the real, lived memory disappears, i.e. 
memory and shapes our understanding of the present moment, i.e. tries to make sense on how "time and memory create stories.”(Young, 2006, 203)

During the research of presentations of contemporary architectural concepts and archaeological heritage, these exhibitions should be considered primarily as institutions, i.e. the place of interaction between different identities through the choice of exhibits, their presentation, spatial disposition, as well as the selection and use of supporting texts. The main emphasis is on defining the exhibition potentials to reflect the change of historical, political and cultural events, and function as a place for promotion of discussions on relevant social and cultural issues.

\section{BIBLIOGRAPHY}

\author{
Albvaš, M. 1999 \\ Kolektivno i istorijsko pamćenje, $R E \check{C}$ - ̌̌asopis \\ za književnost $i$ kulturu, $i$ društvena pitanja (Beo- \\ gard), 56. 2: 74.
}

\section{Asman, A. 1999}

O metaforici sećanja, REČ- časopis za književnost i kulturu, i društvena pitanja (Beograd) 56. 2: 121.

\section{Asman, A. 1994}

Duga senka prošlosti, Beograd: Biblioteka XX.

\section{Bennett, T. 1996}

The Exhibitionary Complex, in Thinking about Exhibition, Reesa Greenberg, Sandy Nairne, and Bruce W. Ferguson (ed.), New York: Routledge: 82.

\section{Curley, N. 2011}

Exhibition, accessed December 20, http://csmt. uchicago.edu/glossary2004/exhibition.htm.

\section{Danto, A. 2006}

Zašto je suspstituciona teorija reprezentacije nespojiva sa tradicionalnim određenjem estetike?,

continues to exist only in the form of reconstructed past. They are established by a social group, and they represent the symbiosis of historiography and group memory (museums, archives, cemeteries, collections, holidays, anniversaries, monuments, etc.).

Pierre Nora, „Između pamćewa i historije. Problematika mjesta”, u Kultura pamćenja i Historija, ur. Maja Brkljačić i Sandra Prlenda (Zagreb:Golden Marketing Tehnička Knjiga,2006), 21-43.
Kritika filozofije umetnosti A.C. Dantoa“, Filozofija i društvo (Beograd), 1: 165.

\section{Gavrilović, Lj. 2007}

O politikama, identitetima i druge muzejske priče, Beograd: Narodni muzej.

\section{Ginzburg, C. 2002}

Representation (The Word, The Idea, The Thing), in Wooden Eyes:Nine reflewctions on Distance, New York: Columbia University press: 63-89.

\section{Greenberg, R., Ferguson B. W. and Nairne, S.,} 1996

Introduction, in Thinking about exhibitions, Reesa Greenberg, Bruce W. Ferguson and Sandy Nairne (ed.), New York: Routledge: 2.

\section{Hall, S. 1997}

The work of representation, in Representation:cultural representations and signifying practices, Stuart Hall (ed.), London: SAGE Publications: 13-75.

\section{Kastelic, M. 2011}

Contemporary exhibition: The rhetoric of the image, accessed December 12., http://koperseminar. pbworks.com/w/page/6815898/Papers.

\section{Kuljić, T. 2006}

Kultura sećanja, Teorijska objašnjenja upotrebe prošlosti, Beograd : Čigoja.

\section{Nora, P. 2006}

Između pamćewa i historije. Problematika mjesta, in Kultura pamćenja i Historija, Maja Brkljačić and Sandra Prlenda (ed.) Zagreb:Golden Marketing-Tehnička Knjiga: 21-43.

Maroević, I. 1994

Izložba kao oblik muzejske komunikacije, Osječki zbornik 21: 290.

\section{Premerl, T. 1970}

Prostorna akcija spomenika, Arhitektura (Zagreb) $106: 70$.

Reigl, A. 1996 (1901)

The Modern Cult of Monuments: Its Essence and Its Development, Karin Bruckner with Karen Wil- 
liams (translators), in: Historical and philosophical issues in the conservation of cultural heritage, Nicholas Stanley Price, Mansfield Kirby Talley, Alessandra Melucco Vaccaro (ed.) Los Angeles: Getty Publications: 69-83.

\section{Svetlana Alpers, S. 1991}

The Museum as a Way of Seeing, in: Exhibiting Cultures, . Ivan Karp and Steven D. Lavine (ed.), Washington, DC: Smithsonian Institution Press: 26.

\section{Young, J. 2006}

Tekstura sjećanja, in Kultura pamćenja i Historija, Maja Brkljačić and Sandra Prlenda (ed.) Zagreb:Golden Marketing - Tehnička Knjiga: 203.

\section{REZIME}

\section{SAVREMENIIZLOŽBENO ARHI- TEKTONSKI KONCEPTI U PRE- ZENTACIJI ARHEOLOŠKOG NASLEĐA}

Ključne reči: sećanje, istorija, izložba,prezentacija, medijum, arheološka prezentacija.

U okviru shvatanja da polje delovanja arhitekture ne obuhvata samo kreiranje sa ciljem zadovoljenja prostornih i utilitarnih potreba, već joj sve više pripada i polje teorijskih razmatranja koje predstavlja prvi korak u postupku objektivizacije u vidu konkretnih objekata ili modela delovanja, ovaj rad se bavio teorijskim razmatranjem kao osnovom za proučavanje arheološkog nasleđa iz pozicije arhitektonskog diskursa. U tom smislu, prikazana je analiza i uspostavljene su relacije između pojmova spomenik, izložba, reprezentacija i sećanje, koji su izdvojeni kao ključni.

$\mathrm{U}$ daljim istraživanjima pored ideje da se istraže savremene interpretacije izlaganja kulturnog nasleđa kao jedan od oblika produkcije savremene arhitektonske prakse, namera je da se prouče i prikažu nevidljive, alternativne istorije kroz izložbu kao medijum, gde je istorija interpretirana kao konstruisan narativ. Potrebno je ispitati na koji način razumevanje prošlosti, a samim tim i društvenih okvira koji je generišu, zavisi od konstrukcije sećanja i na koji način se ono menja. Ovaj pristup je u skladu sa savremenim istraživanjima kulture sećanja koja postavljaju pitanja kako u određenom trenutku vremena pojedino mesto formira sećanje i na koji način ono oblikuje naše razumevanje sadašnjeg trenutka, odnosno pokušavaju da rastumače kako se od "vremena i sjećanja stvaraju prič[e]"1.

Tokom istraživanja savremenih arhitektonskih koncepcija prezentacije arheološkog nasleđa potrebno je ove izložbe razmatrati prevashodno kao institucije, odnosno kao mesto interakcije različitih identiteta kroz izbor eksponata, njihovu prezentaciju, prostornu dispoziciju kao i kroz odabir i upotrebu pratećih tekstova. Glavni akcenat je na definisanju potencijala izložbi da reflektuju promene istorijskih, političkih i kulturnih dešavanja kao i da funkcionišu kao mesta za promovisanje rasprave o relevantnim društvenim i kulturnim pitanjima.

\footnotetext{
1 James Young, „Tekstura sjećanja”, u Kultura pamćenja i Historija, ur. Maja Brkljačić i Sandra Prlenda (Zagreb:Golden Marketing-Tehnička Knjiga,2006), 203.
} 